\title{
Treatment of urinary tract infections with medicinal plants: Monographs of some plants species revealed by traditherapists
}

\author{
Victorien Dougnon, ${ }^{1}$ Phénix Assogba, ${ }^{1}$ Hornel Koudokpon, ${ }^{1}$ Césaire Ayena, ${ }^{1}$ Sosthéne Vissoh, ${ }^{1}$ \\ Géraldine Akpaka, ${ }^{1}$ Jean Robert Klotoe, ${ }^{1}$ Lamine Baba-Moussa, ${ }^{2}$ Honoré Bankole, ${ }^{1}$ \\ Koffi Koudouvo, ${ }^{3}$ Jacques Dougnon ${ }^{1}$ \\ ${ }^{1}$ Research Unit in Applied Microbiology and Pharmacology of Natural Substances, Research Laboratory in \\ Applied Biology, Polytechnic School of Abomey-Calavi, University of Abomey-Calavi; Abomey-Calavi, \\ Benin; ${ }^{2}$ Laboratory of Biology and Molecular Typing in Microbiology, Faculty of Science and Technology, \\ University of Abomey-Calavi, Abomey-Calavi, Benin; ${ }^{3}$ Center for Research and Training on the Medicinal \\ Plants, Laboratory of Physiology and Pharmacology of Natural Substances, University of Lome, Togo
}

\begin{abstract}
Medicinal plants are a precious heritage for humanity and especially for the majority of poor communities in developing countries who depend on them for primary health care and livelihoods. They are used in traditional practices against urinary tract infections without any scientific evidence for most of the species used. This work aims to have a summary of the literature on some medicinal plants used in the treatment of urinary tract infections. To do this, this study was carried out based on the different medic-
\end{abstract}

\author{
Correspondence: Victorien Dougnon, Research Unit in Applied \\ Microbiology and Pharmacology of natural substances, Research \\ Laboratory in Applied Biology, Polytechnic School of Abomey-Calavi, \\ University of Abomey-Calavi, Benin. \\ Tel.: 00229.97736446 \\ E-mail: victorien.dougnon@gmail.com
}

Key words: Traditional medicine; bacterial infection; antibacterial molecule and treatment.

Acknowledgements: The authors would like to thank all the students and members of the Laboratory of Physiology and Pharmacology of Natural Substances, Centre for Research and Training on Medicinal Plants, University of Lome, Togo for their availability and support during this work. They are also grateful to The World Academy of Sciences (TWAS) which supports the research under a TWAS Fellowship for Research and Advanced Training.

Conflicts of interest: The authors declare no conflict of interest.

Contribution: All the authors present in this article have contributed to the realization of this work from the conception of the writing plan, the bibliographical research, the writing of the article, and its proofreading.

Received for publication: 28 October 2020.

Revision received: 28 November 2020.

Accepted for publication: 28 November 2020.

This work is licensed under a Creative Commons Attribution NonCommercial 4.0 License (CC BY-NC 4.0).

${ }^{(C)}$ Copyright: the Author(s),2020

Licensee PAGEPress, Italy

Infectious Diseases and Herbal Medicine 2020; 1:114

doi:10.4081/idhm.2020.114 inal plants cited by herbalists in southern Togo against urinary tract infections. The names of these different plants have each been the subject of research with keywords in search engines such as Google Scholar, PubMed, FreefullPdf, and others to bring out the traditional use of these plants in the world. From all of the above, it appears that the medicinal plant species cited by actors of the Togolese pharmacopoeia are used to treat several diseases in the world. The organs of these plants, such as leaves, bark, and roots are used in the treatment of common illnesses such as typhoid fever, diarrhea, malaria, bronchitis, and hypofertility. Coughs, colds, skin diseases, toothache, gonorrhoea, viral infections, and many other diseases are treated with these plants. The plants are often combined with other plants in traditional medicine. They are used in the form of decoction, fumigation, herbal tea, and others. The type of disease treated by the plants changes from region to region and is also dependent on the culture of the region in the world. The use of medicinal plants is a very ancient practice. It is a very suitable alternative to modern medicine. However, there is a need to have more detailed studies on these plants, such as their toxicological effects.

\section{Introduction}

A human being, in his environment, has taken a growing interest in the study of medicinal plants and their traditional use in different parts of the world. ${ }^{1}$ Medicinal plants are a valuable resource for the majority of rural populations in Africa, with almost $80 \%$ using them to provide basic health care. They use these plants in combination or alone to cure several human diseases. Medicinal plants are therefore a precious heritage for humanity and especially for the majority of poor communities in developing countries who depend on them for primary health care and livelihoods. Over the past two decades, there has been a growing interest in both developed and developing countries in plant-based medicines. ${ }^{1}$ In African countries, plants are the main means of medicine for practical public health care. The work of N'guessan et al., ${ }^{2}$ reports that in traditional medicine, certain plant organs, such as leaves, bark, and roots, are used in the treatment of common illness such as typhoid fever, diarrhea, malaria, bronchitis, hypofertility, and urinary tract infections. Urinary tract infection is one of the most common bacterial infections, in general medicine, after respiratory infections, and the most common in both community and hospital settings, with a rate of $40 \%$. Medicinal plants mainly remain an inexhaustible source of drugs for humans. ${ }^{2}$ The use of traditional medicine is a very common practice in rural areas and even in cities. Several studies are oriented towards medicinal plants to sup- 
port modern medicine in the treatment of certain diseases. For more than two decades, antimicrobial resistance, especially bacterial resistance, has been the most dangerous phenomenon in the world. Consequently, research work in pharmacology is directed towards the search for new molecules that can effectively fight against multi-resistant bacteria and especially against the different forms of resistance in bacteria. Medicinal plants are the last resort for finding an alternative since the very first antibiotic discovered came from plant extracts. Practitioners make several therapeutic uses throughout the world and the traditional uses of medicinal plants generally vary from one region to another and according to the culture of the region. It is to contribute to better use of plants in traditional African practices that this review was initiated to make a brief monograph of the traditional uses of some medicinal plant species used against infectious diseases in the world.

\section{Materials and Methods}

This synthesis study is part of a previous study on medicinal plants used in the maritime region of Togo. This has been based on the plant species obtained at the end of the previous study. To do so, the necessary information on each plant species was searched in different search engines using the following keywords: 'Botanical description of the plant"; "Traditional uses of the plant"; "'Pharmacological properties of the plant"; "'Traditional utility of the plant" and "Antimicrobial activity AND the name of the plant". The search engines used are PubMed, Google Scholar, Researchgate, and Freefull Pdf. The articles obtained have been used according to their reliability and the topic addressed by the article.

\section{Results}

At the end of the various searches carried out using the keywords, it emerges that the medicinal plants used in traditional medicine in Lomé (Togo) are used all over the world against several infectious diseases and other human diseases. These results are presented in the following lines.

\section{Abrus precatorius}

\section{Botanical description of Abrus precatorius}

Abrus precatorius L. of the family Leguminosae is a liana native to the tropical regions of South America, now introduced in all tropical countries. It is an effusive liana climbing to the top of the tallest trees. The branches are hail, hairless, and woody at the base. ${ }^{3}$ The leaves are composed of small, oblong, finely pubescent, paripinnate leaflets. The flowers are pink, long, narrow, and grouped in pedunculated axillary clusters. ${ }^{4}$ The pod is $3-4 \mathrm{~cm}$ long, light brown when ripe, containing 3-4 shiny, $0.5 \mathrm{~cm}$ long, black and red ovoid seeds with a very hard seed coat, not disintegrated during digestion. ${ }^{5}$ It is found in the humid forests of the SudanoSahelian savannas. The parts used are leaves, flowers, roots, stems, and seeds.

\section{Phytochemical composition of Abrus precatorius}

Phytochemical analysis of the leaves of $A$. precatorius showed heterogeneity in the presence of the following chemical groups: alkaloids, tannins, flavones, coumarins, saponins, sterols, triterpenes, and reducing compounds, responsible for the therapeutic and pharmacological properties attributed to A. precatorius. Its roots contain sterol and terpene. ${ }^{6}$

\section{Traditional and/or therapeutic uses}

An ethnomedical study reported that the different parts of $A$. precatorius $L$. are used in fumigation, decoction, maceration, and/or powder form to treat agalactia, dermatosis, pain, fevers, inflammations, sickle cell disease, general fatigue, urinary tract infections, and sterility. ${ }^{7}$ In Madagascar and Senegal, the decoction of the leaves of $A$. precatorius L. is used in the treatment of dry cough in a mixture with tablets and honey.4 In India, the leaves are used to cure fever, stomach disorders, asthma, and bronchitis. In Nigeria, it is used to treat diabetes. ${ }^{8}$ This plant is used in the Togolese and Beninese pharmacopoeia to treat infectious diseases.

\section{Adansonia digitata Linn}

\section{Botanical description of Adansonia digitata Linn}

It is a tree of the Bombacaceae family, which can reach a height of 20 to $30 \mathrm{~m}$ and an average diameter of $7 \mathrm{~m}$. However, in Senegal, there are exceptions with a circumference of up to $21 \mathrm{~m}$. The bark is smooth or fibrous, grey, silvery, or reddish in color. The branches of the baobab tree are tortuous and the spongy interior of the trunk contains a median part that widens with age and forms a conical chamber. The leaves of $A$. digitata have 12 to 18 lateral ribs or veins and a network of very fine translucent veins. The flowers are large, white in color and their corolla is 15 to 20 $\mathrm{cm}$ wide. They are formed of 4 to 5 white petals curved upwards outwards. ${ }^{9}$

\section{Phytochemical composition of Adansonia digitata}

Phytochemical screening of leaf extracts revealed the presence of polyphenols, flavonoids, alkaloids, saponins, and tannins while quinones, sterols, polyterpenes are absent.$^{10}$

\section{Traditional and/or therapeutic uses}

Each part of the baobab tree has one or more medicinal applications, but the most remarkable in Senegalese traditional medicine is undoubtedly the antidiarrheal action of the powder of the pulp and the power of the whole seeds. Dried leaf powder, when absorbed, is said to soothe colic. ${ }^{8}$ The pulverized leaves have the property of maintaining abundant transpiration, preserving fevers and diarrhea, which are frequent in hot countries. It is recommended as an antihaemorrhagic and used as a softener to fight inflammation of the digestive tract and fevers due to malaria. It is also believed to slightly reduce heart rate and increase appetite. These are said to have therapeutic virtues in the treatment of pathologies of the oral cavity, particularly during dental and gum pain, as well as in the fight against jaundice. ${ }^{9}$

\section{Aframomum melegueta}

\section{Botanical description of Aframomum melegueta}

The "maniguette" (Aframomum melegueta), of the Zingiberaceae family, is a perennial plant that produces a brown pod containing many small seeds. This plant is found in subtropical Africa, it is of the genus Aframomum and belongs to the same botanical family as ginger, the Zingiberaceae. The maniguette is also called paradise plant of paradise seed. Herbaceous plants whose stems grow up to $2 \mathrm{~m}$ high from the creeping rhizome. The leaves are stalkless, hairless, lanceolate and 18-22 cm long. The inflorescences are solitary spikes made up of a few flowers of 7 to $13 \mathrm{~cm}$ with bracts. Corollas are white, pink, or purple with a rounded yellow labellum at the base and red at the apex. The fruits are ovoid or fusiform berries, orange and then red. They contain a colorless pulp with a tangy flavor. ${ }^{11}$ 


\section{Chemical composition of Aframomum melegueta}

Phytochemical screening of the various organs of Aframomum melegueta studied revealed the presence of several phytochemical components. These are alkaloids, catechic and gallic tannins, leucoanthocyans, quinonic derivatives, triterpenoids, steroids, mucilages, and free anthracenes. ${ }^{12}$

\section{Traditional and/or therapeutic uses}

Aframomum melegueta K. Schum is used in the treatment of malaria in Cameroon and against diarrhea. ${ }^{13}$ In Benin and Nigeria, the plant is used as a culinary and ritual ingredient and in combination with other plants for the treatment of several diseases. It is also a cure for intestinal infections, stomach burns, and indigestion because it stimulates gastric secretions. Fresh fruit is used as an aphrodisiac. This plant is used to treat dysentery. It has anti-inflammatory and hypotensive activity in humans. ${ }^{14}$

\section{Allium sativum Linn}

\section{Botanical description of Allium sativum Linn}

From the Alliaceae family, bear's garlic is a perennial herbaceous plant with a bulbous, cool, shady undergrowth and white flowers 20 to $50 \mathrm{~cm}$ high. When its foliage is slightly crumpled, it gives off a strong scent. It is considered a social plant that usually forms carpets, flowering from April to June. Leaves are oval $(2-5 \mathrm{~cm}$ wide), long-stalked, soft, full, lanceolate, and sharp at the top; the petiole is flat on one side and rounded on the other. The leaves look like those of the lily of the valley, except that they are non-toxic. The leaves can also be confused with those of colchicum or arum when very young. ${ }^{16}$ The stem is almost triangular, with two sharp, smooth, flat, elliptical-elongated protruding angles with a distinct, welldeveloped blade, sharpened at the top, and gradually tapering to a petiole at the base, with white, star-shaped flowers appearing in late spring. They form an upright ball at the top of the stem. ${ }^{17}$

\section{Chemical composition of Allium sativum}

Phytochemical analysis of Allium sativum revealed the presence of polyphenols, alkaloids, saponins, and tannins. These chemical components are responsible for the biological activity of the plant extracts. ${ }^{18}$

\section{Traditional and/or therapeutic uses}

It is a medicinal plant with a long history of use in the treatment of cardiovascular diseases, diarrhea, and intestinal viruses. It is also used to lower blood pressure, stimulate blood circulation, fight against flu and certain viral or liver pathologies, and specifically against cancers because of its sulfur composition. ${ }^{19}$ Also, this plant is used as a natural antibiotic to relieve viral and respiratory infections thanks to their allicin composition, which protects against many bacteria, viruses, and parasites. ${ }^{19}$

\section{Alstonia boonei De Wild}

\section{Botanical description of Alstonia boonei}

Alstonia boonei, of the family Apocynaceae, is a widespread species from Senegal to Congo, Egypt, Sudan, and Cabinda. In Côte d'Ivoire as in Togo, it is found throughout the forest area, preferably along rivers and in forest galleries in savannah. The tree can reach $40 \mathrm{~m}$ in height, has a straight shaft, and is sometimes grooved. The bark is dark, almost smooth or finely cracked, with abundant latex flowing through the notches. The leaves are whorled by 5 or 8 oblongs, obovate or oblanceolate. They are long wedged at the base, broadened or rounded at the top, stalkless, hairless, glaucous on top. The lateral ribs are numerous. ${ }^{20}$

\section{Chemical composition of Alstonia boonei}

This plant has been widely studied in recent years. But it continues to attract a lot of interest because of the variety of its secondary metabolites. Some are biologically active. The set of compounds isolated and identified is very heterogeneous. Thus, the most common constituents are alkaloids, tannins, steroids, triterpenoids, phenolic components, cardiotonic glycosides, and organic acids. ${ }^{21}$

\section{Traditional and/or therapeutic uses}

Alstonia boonei has a great reputation as an antimalarial agent in tropical countries. According to the work of some authors on the use of Alstonia boonei, the result is that the species is diversely used depending on its geographical location on the continent. In Nigeria, the bark and the root are considered to be ordinary febrifuge and anti-malarial drugs. In Ghana and Cameroon, bark decoction is also used against malaria. In India, Alstonia's bark is used against malaria and chronic diarrhea with a lesser effect than cinchona bark but without side effects. In Burkina Faso and Ivory Coast, bark decoction is used to clean suppurative wounds and open fractures. Moreover, in the Ivory Coast bark macerate is used against jaundice, sap against coughs, and sore throats, and externally against skin diseases. According to the survey and research work of some authors, bark, root, and leaves are used to relieve rheumatic pain and several other pains. ${ }^{21}$

\section{Annona senegalensis $L$.}

\section{Botanical description of Annona sengalensis $L$.}

Annona senegalensis, of the family Annonaceae, is a shrub up to $4 \mathrm{~m}$ high, with irregular, open tops, smooth, grey bark with a pinkish edge. The leaves are alternate, widely oval or oblong, 7-20 x 6-12 cm, fragrant when crumpled. Blade with a rounded apex and rounded base with a more or less pubescent and lighter underside. Stalk thickened at the base, ribbed at $7-12$ pairs, parallel veins. The flowers are isolated by 2 or 3 in the axils of the leaves, yellowish-white like bells. Fruits are green in color. They are globular with a diameter of $3-4 \mathrm{~cm}$ and are formed by the fusing of all the fleshy carpels. Each carpel contains a small seed coated in a sweet mucilage. ${ }^{22}$

\section{Chemical composition of Annona senegalensis}

Analysis of these results shows that all the extracts studied contain flavonoids, anthraquinones, tannins, sterols and tri-terpenes, coumarins, anthocyanins, catechic tannins, coumarins, mucilages, and saponosides. ${ }^{23}$

\section{Traditional and/or therapeutic uses}

The leaves of $A$. senegalensis are traditionally used against dysentery, tuberculosis, diabetes, diarrhea, fever, and nephritis. The root decoction is used against tuberculosis, gastritis, snake bite, erectile dysfunction, syphilis, amoebic dysentery. Bark and twigs are also used against internal and external bleeding. The hydro-ethanolic extract of the leaves of $A$. sengalensis has demonstrated properties. Several researchers have demonstrated that extracts from the leaves of this plant have antifalcifying, antimicrobial, antidiarrheal, antiparasitic, anti-inflammatory and analgesic, antioxidant, anthelmintic, anticonvulsant, insecticidal, and anti-tumor activity. ${ }^{24,25,26}$

\section{Anthocleista nobilis}

\section{Botanical description of Anthocleista nobilis}

In the family Loganiaceae, these are mainly trees and shrubs, usually with woody stems. The leaves are opposite, simple, and stipulate. The flowers are hermaphrodite, usually actinomorphic 
with ovaries larger than 2-4 cells. Fruits can be capsules, drupes, or berries. Their leaves are hairless, tough, and large. The base of the leaf stem is dilated and sometimes more or less winged. The leaves of these species vary from oval to lanceolate and are clustered at the ends of the twigs, usually 6 to 18 inches long; and the flowers are 1 to 3 inches long. The color of the flowers varies from white to cream. ${ }^{27}$

\section{Chemical composition of Anthocleista nobilis}

The phytochemical screening carried out on this species revealed the presence of tetracosans, pentacosans, flavonoids, and polyterpenes. Anthocleista nobilis contain a quinolic alkaloid, brucine, and a monoterpene heteroside. ${ }^{28}$

\section{Traditional and/or therapeutic uses}

A. nobilis is commonly used throughout its range for its powerful purgative and diuretic properties. The root decoction is generally taken to treat constipation and for its emmenagogic and abortifacient virtues. It is used to treat leprosy, venereal diseases, edema, and elephantiasis of the scrotum. In Sierra Leone, the root decoction is taken with lemon against hepatitis. Bark pulp is used as an enema to treat intestinal parasites. The bark decoction can be drunk or used in a steam bath to treat fever, stomach ache, leprosy, gonorrhoea, and dysmenorrhoea. In Senegal, Liberia, and Ghana, stem bark or powder from young green twigs is applied fresh or in paste form to wounds, abscesses, or ulcerated sores. The stem bark of Anthocleista nobilis and Zanthoxylum gilletii (De Wild.) P.G.Waterman is reduced to a paste and applied locally to treat rheumatism. In Liberia, bark infusion is given to dogs suffering from diarrhea. ${ }^{29,30}$

\section{Bridelia ferruginea Benth}

\section{Botanical description of Bridelia ferruginea}

$B$. ferruginea is a small tree that is widespread in the wooded savannahs and open forests of Sudanian and Sudano-Guinean Africa. It belongs to the Euphorbiaceae family. Its zyzagging branches bear alternate, oblong leaves, in the axils of which are glomerules of yellowish flowers followed by ellipsoidal, black, and hard edible fruits. In Côte d'Ivoire, this plant is abundantly represented from the prelagunate savannahs to the north of the country. ${ }^{31}$

\section{Chemical composition of Bridelia ferruginea}

The phytochemical study of the aqueous extract of Bridelia ferruginea showed that this plant contains quinones, catechic and gallic tannins, alkaloids, sterols, polyterpenes, polyphenols, reducing compounds, flavonoids, and saponosides. ${ }^{23}$

\section{Traditional and/or therapeutic uses}

B. ferruginea is a plant used in the traditional African Pharmacopoeia as a purgative, diuretic, aphrodisiac, and antiblennorrhagic. It is used in the treatment of illnesses such as febrile seizures, dysentery, lung infection, rheumatic fever, erythema, chickenpox, thrush, mouth ulcers, and toothache. This plant is used as a laxative and purgative. ${ }^{31}$ In Rwanda, the leaves of this plant species are used to treat gastroenteritis. In Mali, the roots are used to treat dysentery or hypotension, while the bark is used to treat colic, constipation, conjunctivitis, or gingivitis. The leafy shoots are used as diuretics or as a febrifuge, if not in cases of hemoglobinuria biliary fever, jaundice, stomach aches, or malaria. In Côte d'Ivoire, Malinke uses root decoction in mouthwashes to cure thrush in children and leaf decoction to wash the patient in the treatment of chickenpox. ${ }^{31}$

\section{Caesalpinia bonduc Roxb}

\section{Botanical description of Caesalpinia bonduc Roxb}

C. bonduc, of the family Caesalpiniaceae, is a species of shrubs of the family Caesalpiniaceae according to the classical classification, or Fabaceae according to the phylogenetic classification. This sarmentous shrub is entirely covered with short, very sharp, yellowish or brown, straight, or curved spines of 2 to $4 \mathrm{~mm}$. Its large foliate stipules, deeply and irregularly 3 to 4 lobed and persistent, distinguish it from a related species, $C$. ciliata. It has large, bipinnate leaves, 30 to $70 \mathrm{~cm}$ long, a pubescent rachis, and armed with curved spines. The axillary raceme is very elongated (up to $60 \mathrm{~cm}$ ), erect, and bears numerous flowers with 5 yellow or brownish petals and 10 stamens. Flowering takes place from September to January in the West Indies. ${ }^{31}$

\section{Chemical composition of Caesalpinia bonduc}

Phytochemical analysis of this plant reveals that it is made up of different chemical groups, namely: alkaloids, gallic and catechic tannins, coumarins, anthocyanins, leucoanthocyans, quinonic derivatives, triterpenoids, steroids, saponosides, and reducing compounds. It also contains free anthracenes and O-heterosides. ${ }^{32}$

\section{Traditional and/or therapeutic uses}

Throughout C. bonduc's range in Africa, its leaves bark, and roots are used to treat fever, headaches, and chest pains. They also serve as a deworming agent. In West Africa, the plant is used as a rubefacient and tonic in the treatment of jaundice, diarrhea, and skin rashes. On the Kenyan coast, the seed and decoctions of leaves and roots are taken to treat asthma and complications during menstruation and to prevent miscarriages. They are also administered as eye drops to treat internal blood clots in the eye. In Tanzania, the almond from the ground seed is taken with water to treat diabetes mellitus. In Somalia, the oil from the seeds is used to treat rheumatism. ${ }^{29}$

\section{Capsicum annuun $L$.}

\section{Botanical description of Capsicum annuun $L$.}

Belonging to the Solanaceae family, the chilli pepper is native to America and cultivated all over the world. This small shrub can reach $3 \mathrm{~m}$ in height and persist for a few years if it is found in sufficient conditions to survive, otherwise, it is considered an annual plant. It has a characteristic appearance with its stem dividing into two equal parts at each branch. Its flowers do not grow taller than $1 \mathrm{~cm}$, they have white star-shaped petals. The fruits are berries of varying shape and color, most often elongated conical, red, or orange, and can be up to $10 \mathrm{~cm}$ long. ${ }^{33}$

\section{Chemical composition of Capsicum annuum $L$.}

The phytochemical study of Capsicum annuum has shown that this plant contains quinones, polyphenols, and flavonoids as well as tannins. ${ }^{34}$

\section{Traditional and/or therapeutic uses}

Pepper leaves are applied to skin fungi and boils. The fruit used as a condiment is considered to strengthen the body. The fruit contains mainly alkaloids, carotenoids, flavonoids, oils, saponins, and many vitamins. In external use (compress), tonic, sweat-inducing, it has the particularity of being anti-inflammatory, decongestant, vasodilator, rubefacient, and revulsive. The leaf has antiseptic properties. A reasonable amount of crushed chilli pepper is put on a cloth and applied to the painful parts. Whether internally (diet) or external, moderate use of chilli pepper is recommended. ${ }^{33,35}$ 


\section{Cassia sieberiana DC}

\section{Botanical description of Cassia sieberiana DC}

From the Caesalpiniaceae family, it is a small tree of 8 to $10 \mathrm{~m}$, often less, with a short, contoured shaft, frequently branched near the base. Cracked, lamellar bark, dark in older trees. Branches are flexuous and drooping. Composite leaves pinnate, dark green, with 6 to 12 pairs of glossy leaflets on top, oblong, lanceolate, widely acuminate but obtuse at the top, with oppressed hairs on the underside, with depressed midrib above, very protruding below. Stalks about $3 \mathrm{~cm}$ long, petioles $5 \mathrm{~mm}$ long. Flowers in hanging clusters golden yellow. Each flower can be pedicled up to $5 \mathrm{~cm} .{ }^{36}$

\section{Chemical composition of Cassia sieberiana}

The phytochemical screening carried out has shown that the leaves, bark, and roots of Cassia sieberiana contain flavonoids, anthraquinones, tannins, reducing compounds, mucilages and coumarins. However, free quinones and alkaloids are absent in all three parts of the plant. ${ }^{37}$

\section{Traditional and/or therapeutic uses}

In Senegal, C. sieberiana is used as a purgative, diuretic, to treat constipation, anuria, dysuria, stomach pain, intestinal parasites, leprosy, edema, venereal diseases and impotence, sterility, kidney pain, fever, aches, and pains. In Sierra Leone, a root extract is used to treat the strangulated hernia. The roots are also taken against constipation. In Côte d'Ivoire, a root decoction is taken in high doses as a tenifuge. ${ }^{31}$ In Mali, macerated roots are used in visual disorders, onchocerciasis, and its consequences. In Burkina Faso, root decoction is used in the treatment of abdominal pain, gonorrhoea, and jaundice. In Ghana, root powder is taken with water against snake bites. The roots are used in cases of dysentery and haemorrhoids. Bark powder is given against gonorrhoea and the roots and fruit pulp together are purgative and stomachic and remedy dizziness or intoxication. A decoction of Cassia sieberiana roots mixed with natron is used against coughs. ${ }^{36}$

\section{Ceiba pentandra (L.)}

\section{Botanical description of Ceiba pentandra}

It is a large tree belonging to the Bombacaceae family. In Latin America, its total height reaches $70 \mathrm{~m}$ and its diameter is close to $300 \mathrm{~cm}$. The trunk is cylindrical, often slightly convex. The open umbrella-shaped top is spherical to round. The numerous verticillated branches slope gently upwards. The bark is smooth and green. When the tree grows larger, it becomes pale grey and cracks in the form of horizontal rings advancing in lenticels form. Conical spines emerge from the bark, especially in young trees. The roots of large kapok trees are characterized by their ribbon-like, convex buttress development. It spreads up to more than $9 \mathrm{~m}$ around the base. The leaves are alternate, palmated, digitally compound, dark green above and pale green below. The edge is entire. The leaves are 10 to $45 \mathrm{~cm}$ long and 5 to $20 \mathrm{~cm}$ wide. The flowers are fasciculated in pendulous form, grouped axillary in twigs. They are broad, whitish in color, and have an unpleasant smell. ${ }^{38}$

\section{Chemical composition of Ceiba pentandra}

The phytochemical screening carried out showed the presence of flavonoids, steroids, saponins, and terpenoids. ${ }^{39}$

\section{Traditional and/or therapeutic uses}

C. pentandra has two main uses, as it is both an important source of fiber and timber. Traditionally, it has been most important as a source of kapok, which is the fiber from the inner wall of the fruit. Kapok is used to stuff cushions, pillows, and mattresses; it is also an insulating and absorbent material. But it is attracting renewed interest, as it offers opportunities in textiles, thanks to new processing techniques. The fiber may also offer a biodegradable alternative to synthetic oil adsorbents because of its hydrophobic-oleophilic properties. ${ }^{38}$

\section{Cocos nucifera Linn.}

\section{Botanical description of Cocos nucifera Linn.}

C. nucifera Linn of the family Arecaceae in monocotyledonous plants. They are therefore not trees, but "giant grasses". They are easily recognizable by their unbranched stem, the stipe, topped by a bunch of pinnate leaves. The Arecaceae are widespread throughout the intertropical zone. The size of the plant, leaves, and fruits makes it possible to differentiate and recognize this species. ${ }^{40}$

\section{Chemical composition of Cocos nucifera}

On a phytochemical level, the constituents found in the hydroalcoholic and aqueous extract of this plant are sterol-polyterpenes, alkaloids, flavonoids, tannins, and saponins. On the contrary, free or combined quinonic substances have not been detected in these extracts. ${ }^{41}$

\section{Traditional and/or therapeutic uses}

The coconut, i.e. the solid and liquid part of the nut, is used for these many health benefits. Indeed, it has antiseptic, antitumour, anthelmintic, aphrodisiac, astringent, bactericidal, diuretic, haemostatic, spasmodic, pedicular, cooling, cardiotonic, and vermifuge properties. Dietary fibre from coconut albumen also has antimalarial activities. ${ }^{41,42}$ This plant also has anti-infectious properties according to herbalists in the South Togolese markets.

\section{Cola millenii K. Schum}

\section{Botanical description of Cola millenii}

C. millenii of the family Sterculiaceae is a tree that can reach $18 \mathrm{~m}$ in height, even $20 \mathrm{~m}$, but rarely with a shaft up to $50 \mathrm{~cm}$ in diameter. The leaves are thin and lobed. The lobes are weakly acuminate. Cymes inflorescences are very short and axillary. The flowers are short-stalked with greenish sepals on the outside, redbrown or purple on the inside. The fruits are made up of follicles, pink-rich or reddish-orange, arranged in stars with short rays more or less numerous at the top of a common stalk and containing several seeds. The seeds are buried in a whitish pulp acidulous and sweet. The bark is fibrous and the wood is white and soft. ${ }^{43}$

\section{Chemical composition of Cola millenii}

The phytochemical screening performed showed the presence of flavonoids, steroids, and saponins. ${ }^{44}$

\section{Traditional and/or therapeutic uses}

Local names for C. millenii vary from one socio-cultural group to another. The use of $C$. millenii in food is documented by several authors. Young leaves of the species are poorly consumed. ${ }^{45}$ Similarly, the use of its leaves in the traditional treatment of several diseases has been reported due to their medicinal properties. The leaves of this plant are generally used against malaria, fever, jaundice, dysentery, conjunctivitis, gonococcus, abscesses and skin rashes, female infertility, hematic conditions, salmonellosis, and chicken pox. The bark extract contains active ingredients that can be used to control the infestation of corn kernels by Prostephanus truncatus. Its wood is also used for various purposes. In Nigeria, C. millenii is a species of high economic value. It is also traded in Togo and Benin. ${ }^{46}$ 


\section{Cymbopogon citratus Stapf}

\section{Botanical description of Cymbopogon citratus Stapf}

This perennial grass grows in clumps of thirty to $60 \mathrm{~cm}$ in height. It belongs to the Poaceae family. The leaves are covered with rough hairs. The whole plant gives off a lemon scent when crumpled. $^{38}$

\section{Chemical composition of Cymbopogon citratus}

Phytochemical screening of leaf extracts revealed the presence of polyphenols, flavonoids, alkaloids, saponins, and tannins. ${ }^{47}$

\section{Traditional and/or therapeutic uses}

The decoction of lemongrass leaves is drunk to facilitate digestion. It is also used to fight against fevers, headaches, and rheumatic pains. The plant is devoid of toxicity. It is however strongly advised to filter the tea correctly to avoid irritation of the oesophagus by the micro hairs present on the leaf. The aerial parts are antispasmodic, antiseptic, analgesic, anti-inflammatory, diuretic and help fight against fever. The plant is also sometimes used to keep insects away. For this, it is recommended to use only the lighter part of the lower part of the plant. ${ }^{38}$

\section{Ficus platyphylla Del}

\section{Botanical description of Ficus platyphylla Del}

It is a large tree that can reach $20 \mathrm{~m}$ high with a diameter of 2 $\mathrm{m}$. It belongs to the family Moraceae. The bark of the trunk is light grey, sand, or rust on young subjects, with exuding pink edges with abundant latex. The crown is very spread out, strongly framed with large leaves ( 5 to $26 \times 20 \mathrm{~cm}$ ). The receptacles are composed of two opposite bracts. The bracts are all pointing downwards. They are in axillary pairs or on old wood, solitary or in groups. The flowers consist of a stamen. ${ }^{48}$

\section{Chemical composition of Ficus platyphylla}

The phytochemical screening carried out showed the presence of flavonoids, steroids, and saponins. ${ }^{48}$

\section{Therapeutic and/or traditional uses}

The fruit has analgesic activity. In Nigeria, the methanolic extract of $F$. platyphylla has shown dose-dependent inhibition of gastrointestinal motility on isolated rabbit jejunum and rabbit duodenum. In 2002, the same authors reported that the aqueous extract of F. platyphylla stem bark had significant dose-dependent antiinflammatory and nociceptive effects. The extract also prevented acetic acid-induced pain in mice and reduced formalin-induced pain episodes. Locomotor and exploratory activities were significant on the methanolic extract of $F$. platyphylla stem bark. Methanolic extract of Ficus platyphylla stem bark indicated peripheral and central analgesic effects in mice. This plant is used in Togolese pharmacopoeia against infectious diseases. ${ }^{48}$

\section{Gomphrena celosioides Mart}

\section{Botanical description of Gomphrena celosioides}

G. celosioides, is a plant of the family Amaranthaceae. More than 140 species of the same family are found in America, 46 of which are in Brazil. Very few species are present in East and West Africa. It is an annual or perennial species, pubescent, spreading with taproots, woody, about $20 \mathrm{~cm}$ high, and propagated by seeds. The stem is slender, weak, contracted into knots and the upper part is covered with white hairs. ${ }^{49}$

\section{Chemical composition of Gomphrena celosioides}

Research has revealed the presence of saponins, steroids, amino acids, non-reducing sugars, phenols, and flavonoids in Gomphrena celosioides. ${ }^{50}$

\section{Traditional and/or therapeutic uses}

In Nigeria, this plant is used for the treatment of various skin conditions. It also has analgesic, tonic, carminative and diuretic properties. In Benin, traditional therapists use this plant in the treatment of jaundice, malaria, and dysmenorrhea. However, little information exists on its hepatoprotective properties. It is therefore important that work be undertaken to provide a scientific basis for the use of this plant in the treatment of liver diseases. It is recognized that silymarin administered orally opposes the increase in serum transaminase levels resulting from carbon tetrachloride intoxication. This plant is used in association with other plants in Togolese medicine to treat urinary tract infections but no scientific study has yet evaluated this antimicrobial property. ${ }^{50}$

\section{Hibiscus sabdariffa Linn}

\section{Botanical description of Hibiscus sabdariffa Linn}

$H$. sabdariffa $L$. of the family Malvaceae is a large, vigorous, unbranched, and very fibrous plant. It is mainly cultivated for its fibres. The variety sabdariffa L. is a bushy plant with edible calyxes. It is an annual plant with a highly developed and persistent flower calyx, which is used to prepare tea and the widely consumed local drink (bissap). The stem is cylindrical, fibrous, light green, or dark purplish red, sometimes with a longitudinal line of tomentose pubescence, changing position at each internode, glabrescent to slightly hispid. It is glabrous to slightly pubescent, sometimes with a few stings, green or reddish. ${ }^{51}$

\section{Chemical composition of Hibiscus sabdariffa}

Phytochemical screening shows that apart from the presence of the three (03) groups of phenolic, nitrogen, steroid, and terpenoid compounds, we have cyanogenic derivatives, mucilages, and reducing compounds. ${ }^{52}$

\section{Traditional and/or therapeutic uses}

Several authors have reported on the pharmacological properties of bissap. Bissap occupies an important place in traditional medicine. Indeed, several properties have been reported: antispasmodic, hypotensive, deworming, antimicrobial, and antifungal. Other properties are also known: aphrodisiac, bile duct, emollient, and laxative. Calyxes, leaves, and flower buds are used in the preparation of cures against viral hepatitis and coughs. The calyxes contain gossypeptin, anthocyanins which facilitate blood circulation and lower blood pressure. The emollient or laxative properties seem to be due to saponins which are natural detergents with glucosides. These medicinal properties have been the subject of clinical studies carried out for the most part on animals by some. It is also used to treat liver diseases and fever, it is an antioxidant, anticancer, it contains organic acids and other vitamin compounds. It is rich in polyphenols and three times richer in vitamin $\mathrm{C}$ than an orange. ${ }^{52,53}$

\section{Holarrhena floribunda (G. Don) Dw. Sch.}

\section{Botanical description of Holarrhena floribunda}

H. floribunda, of the Apocynaceae family, is a small tree with a slender shaft that can reach a height of about $15 \mathrm{~m}$. The leaves are simple, oval to the oblong, opposite, whole, acuminate to suboblong, 7 to $15 \mathrm{~cm}$ long, and 5 to $8 \mathrm{~cm}$ wide. They are membranous and have very prominent veins underneath and a short petiole ( 5 to $8 \mathrm{~cm})$. The whitish, small, fragrant flowers group together as an inflorescence and form terminal or axillary corymbs. The fruit is a 
long, slightly curved, blunt-tipped, blackish follicle. The leaves turn yellow around January or February and then fall off. ${ }^{54}$

\section{Chemical composition of Holarrhena floribunda}

The phytochemical study showed that this present contains alkaloids, progesterones, polyphenols, and flavonoids. ${ }^{54}$

\section{Traditional and/or therapeutic uses}

The use of plants of the genus Holarrhena in traditional medicine dates back to the year $1000 \mathrm{BC}$. The inhabitants of the East Indies used them for the treatment of acute and chronic dysentery. It is attributed to the following properties: Crushing the bark drunk in acid milk stops dysentery and hemorrhoids. The decoction of the root is active against angina, arthritic pain, and even toothache. The seeds used in decoction fight against fever, hepatitis, and gout. ${ }^{54}$ In Africa, several ethnobotanical works reveal the use of $H$. floribunda in the cure of several pathologies. Thus $H$. floribunda is used against dysentery and sterility, as a febrifuge and diuretic. The bark macerate, administered orally, is indicated against intestinal parasitosis, gonorrhoea, and sterility. The decoction of bark and leaves, according to some matrons in Senegal, as a drink and bath is recommended throughout the woman's gestation period and for women facing abortion problems. Dioulas use the decoction of the roots alone or combined with the leaves to treat painful menstruation. ${ }^{54}$

\section{Jatropha gossypifolia Linn}

\section{Botanical description of Jatropha gossypifolia Linn}

$J$. gossypifolia is a small bushy shrub, 1-2 m high. It belongs to the family Euphorbiaceae. The leaves are usually three-lobed and alternate. The petiole is 8 to $12 \mathrm{~cm}$ long and bears scattered glandular branched hairs. The plant is easily reddish. The flower is in an unbranched terminal panicle. The branches bear sub-sessilic, reddish-green, $6 \mathrm{~mm}$ wide flowers that barely open. The fruit is a $12 \mathrm{~mm}$ wide, three-lobed capsule. It is glabrous, each lobe has a slight median groove. ${ }^{55}$

\section{Chemical composition of Jatropha gossypifolia}

The phytochemical analysis shows the presence of groups of phenolic, nitrogen, steroid, and terpenoid compounds. ${ }^{56}$

\section{Traditional and/or therapeutic uses}

The plant is used in villages to keep lightning away. It is also said to be used successfully against leprosy and rabies. The 7 to 25 leaves of the plant in decoction are said to be a cure for dry colic. The infusion of the leaves would be febrifuge, while the decoction would be purgative. The leaves in sauce associated with those of Plumbago zeylanica are used in the treatment of dysmenorrhoea. The aqueous decoction of the roots of the plant-associated with those of Cassia occidentalis is used in inhalation and as a drink in the treatment of convulsive crises. In cases of sterility, the cold decoction of the leaves is drunk with lemon juice. The juice of the leaves is used per os in the treatment of anemia and sexual asthenia. A watery decoction of the leaves is used orally in the treatment of diabetes, coughs, high blood pressure, vomiting, and rash fevers. The aqueous macerate of the leaves per os is said to treat gastralgia, painful periods, and seizures in children. The juice that flows from the stems through an incision would act very well against ulcers. The seed is used against intestinal obstructions and rheumatism. ${ }^{56,57}$

\section{Khaya senegalensis (Desr.) A. Juss}

\section{Botanical description of Khaya senegalensis}

$K$. senegalensis, of the family Meliaceae, is a tree that can grow up to $35 \mathrm{~m}$ high and 60 to $100 \mathrm{~cm}$ in diameter. The leaves are paripinnate and alternate. The rachis is 12 to $20 \mathrm{~cm}$ long and can bear 4 to 6 pairs of oblong leaflets, usually 2 to 3 times longer than wide, 7 to $10 \mathrm{~cm}$ long, 20 to $40 \mathrm{~mm}$ wide, sometimes in a very wide oval shape. Their base is wedge-shaped, a little asymmetrical and their apex ends in a short abrupt rounded point. The flowers are tetrameric, i.e. formed of successive whorls of four flower pieces. The calyx has four interlocking sepals, the white corolla is 7 to $8 \mathrm{~cm}$ wide and has 4 petals surrounding the narrow, centrally erect stamens crown. The pedicels measure 2 to $4 \mathrm{~mm} .{ }^{58}$

\section{Chemical composition of Khaya senegalensis}

The work on the phytochemistry of Khaya senegalensis reveals on the one hand the presence of a high quantity of polyphenolic compounds (catechic tannins, anthocyanins, and leucoanthocyanins); saponins; fewer anthracene derivatives, and very few steroids. This plant also contains flavonoids. ${ }^{59}$

\section{Traditional and/or therapeutic uses}

This plant is used for anti-malarial and gastrointestinal disorders. The barks would be endowed with purgative and antientéralgic properties. The root extracts are used against gum inflammation. This plant is used as an antidysenteric. Root extracts are used against tapeworms. The flowers are used for the treatment of venereal diseases, syphilis, gonorrhoea. It is also used in various forms (decocted, macerated) for internal and external use both in the treatment of leprosy, syphilis, chickenpox, and in this case the leaves are added to the various preparations. The root extracts are used against jaundice, for the disinfection of bloody, ulcerated wounds and smallpox. Bark and leaf macerate is used in the treatment of senescence. The powdered and prized leaves are used against headaches. Root extracts are used against dermatoses, scabies, scorpion stings, allergies, and leaves are used against neuralgia. ${ }^{58}$

\section{Kigelia Africana (Lam.) Benth.}

\section{Botanical description of Kigelia africana}

Semi-caducifoliate tree, small to medium size, up to $25 \mathrm{~m}$ high with long and low branches; grey, smooth or flaky bark; rounded crown. It belongs to the family Bignoniaceae. Leaves opposite or whorled, usually in whorls, usually gathered towards the end of the branches, imparipinnate, up to $60 \mathrm{~cm}$ long; stipules absent; petiole up to $15 \mathrm{~cm}$ long. Bisexual flowers, very large; pedicel, curved upwards at the tip; calyx slightly tubular to campanulate. ${ }^{60}$

\section{Chemical composition of Kigelia africana}

Phytochemical screening of the bark of this plant revealed the presence of alkaloids, catechic and gallic tannins, flavonoids, anthocyanins and leucoanthocyans, quinonic derivatives, triterpenoids, steroids, saponosides, mucilages, reducing compounds, free anthracenes, combined C-heterosides and combined O-heterosides anthracenes. ${ }^{32}$

\section{Traditional and/or therapeutic uses}

$K$. africana is widely used throughout Africa for multiple purposes, but particularly in local medicine. Diseases against which the plant is used include syncopes, anemia, sickle cell disease, epilepsy, respiratory insufficiency, liver and heart problems, and nutritional diseases such as kwashiorkor, rickets, wasting and weakness. Roots, bark, leaves, stems, twigs and fruits are used to 
treat digestive disorders. Infections of the genitourinary tract, especially venereal diseases, are treated internally and externally with preparations of roots, bark, leaves, stems and twigs. In West and Central Africa palm wine is drunk, in which dried and crushed bark is macerated to cure syphilis. Childhood venereal diseases are treated jointly with a drink and a bath prepared from a bark decoction. Kigelia africana is widely used to treat gynecological diseases. Powders and infusions of bark, leaves, stems, twigs or fruit are used to clean and dress superficial and open wounds. ${ }^{60}$

\section{Lippia multiflora}

\section{Botanical description of Lippia multiflora}

L. multiflora, of the family Verbenaceae, is an upright, woody aromatic plant with pubescent angular stems and a more or less smooth bark, reaching up to 2 or $4 \mathrm{~m}$ in height. The strain of lippia multiflora has many roots, including the main root, which has a vertical orientation, and many secondary roots, with a subhorizontal orientation. The leaves are pubescent and strongly aromatic. The shape and color of the leaves of lippia multiflora differ from one variant to another. ${ }^{61}$

\section{Chemical composition of Lippia multiflora}

Research has revealed the presence of saponins, steroids, amino acids, non-reducing sugars, phenols, and flavonoids. ${ }^{62}$

\section{Traditional and/or therapeutic uses}

The leaves of L. multiflora are traditionally used as a decoction to treat bronchial disorders such as feverish attacks, rhinopharyngitis, conjunctivitis, and jaundice. The aqueous extract of its leaves produces a deeply calming effect. It has a pleasant natural scent. Its infusion normalizes blood pressure, facilitates digestion, and is good for relaxation. In rural communities in West and Central Africa, only L. multiflora tea has been observed to be consumed after work in the fields, allowing good relaxation and increasing sleep. The tranquilizing and analgesic aspects of the infusion of the leaves have been shown. This plant has antipyretic and antiinflammatory properties. Concerning anti-malarial activity, work has shown that aqueous extracts of $L$. multiflora have anti-malarial activity in vitro. A decoction of the leaves of the plant would also have antimalarial and antihypertensive properties. The leaves of $L$. multiflora showed the greatest activity against Anopheles gambiae eggs and Anopheles aegyptiaca larvae. In Ghana, this plant is used as an infusion to treat stomach aches. Besides, Lippia multiflora leaves in the form of a steam bath are used to treat coughs, colds, sleeping sickness, and yellow fever. ${ }^{62}$

\section{Mangifera indica Linn.}

\section{Botanical description of Mangifera indica Linn}

It is a tree that can reach a height of 8 to $15 \mathrm{~m}$. Belonging to the Anacardiaceae family, it is characterized by a large, spreading crown, providing magnificent shade all year round. Its trunk can reach $1 \mathrm{~m}$ in diameter. Its bark is smooth, dark grey-brown to black. In Sahelian countries, its roots sink very deep down to about $8 \mathrm{~m}$, which explains the resistance of adult plants to a lack of rainfall. The leaves are alternate, whole, oblong, lanceolate to oval, wedge-shaped at the base, and acuminate at the top. The flowers are either hermaphroditic or male flowers. ${ }^{22}$

\section{Chemical composition of Mangifera indica}

The phytochemical screening carried out on the leaves and bark showed the presence of flavonoids, anthraquinones, tannins, reducing compounds, mucilages, and coumarins. However, free quinones and alkaloids are absent in all three parts of the plant. ${ }^{22}$

\section{Traditional and/or therapeutic uses}

The infusion of bark from the trunk has astringent, anti-dysentery, and anti-blennorrhagic properties. It would also be antirheumatic. The bark is also used against fevers, scabies, skin diseases in general, leucorrhoea, metrorrhagia. It is an excellent vomitor. The infusion of bark and roots is recommended against diarrhea and dysentery. Bark macerate is used to stop common diarrhea. Bark decoction is used in a gargle to treat sore throats, mouth ulcers, gingivitis, and other mouth sores. The infusion of flowers and leaves is pectoral, deworming, sudorific, and antiscorbutic. The leaves are considered diuretic and febrifuge. Rich in tannins and astringent, it is made into a decoction that is used as a gargle in the treatment of angina and as a mouthwash against toothache. The decoction of the leaves is also used in the treatment of asthma. Numerous researches carried out on different parts of Mangifera indica have indicated that this plant has several important pharmacological properties. ${ }^{22}$

\section{Monodora myristica (Gaertn.) Dunal}

\section{Botanical description of Monodora myristica}

M. myristica of the family Annonaceae is a tree of 30 to $35 \mathrm{~m}$ in height and $70 \mathrm{~cm}$ in diameter, with a grooved base, a straight shaft, and a wide crown. The branches are spread out horizontally and the foliage is dense. The leaves are deciduous, alternate simple, rounded, or cordate at the base. The bark is grey, with anastomosing and fragrant cracks. Fruits are spherical, worm-like, woody, and thick-shelled. This plant of the Annonaceae family is found in tropical Africa, from Sierra Leone to Angola and Uganda. It is often found in Cameroon in scattered secondary forests. ${ }^{2}$

\section{Chemical composition of Monodora myristica}

Phytochemical screening revealed the presence of alkaloids, catechic and gallic tannins, flavonoids, anthocyanins and leucoanthocyans, quinonic derivatives, triterpenoids, steroids, saponosides, mucilages, reducing compounds, free anthracenes, combined $\mathrm{C}$-heterosides and combined O-heterosides. ${ }^{32}$

\section{Traditional and/or therapeutic uses}

Fruit seeds are used in the treatment of abdominal pain, migraine, fever, intestinal parasites, diarrhea, and high blood pressure. The leaves of this plant are sold by herbalists in the markets of Benin (South Benin) and Togo (Lomé) to treat infectious diseases. $^{2}$

\section{Morinda lucida Linn}

\section{Botanical description of Morinda lucida Linn}

The M. lucida Benth species of the family Rubiaceae is usually a very eclectic small tree. It is found in coastal thickets and coastal savannahs, sometimes as a simple shrub, sometimes as a tree reaching $15 \mathrm{~m}$ in height and $0.40 \mathrm{~m}$ in diameter. But it also exists in the forest, where it is a large tree $25 \mathrm{~m}$ high and $0.60 \mathrm{~m}$ in diameter. The rough, scaly bark breaks into small scales with brittle yellow-brownish slices; sometimes the slices are whitish with brown granulation. Yellow wood appears immediately under the bark. ${ }^{63}$

\section{Chemical composition of Monodora myristica}

Phytochemical screening revealed the presence of alkaloids, catechic and gallic tannins, flavonoids, anthocyanins and leucoanthocyans, quinonic derivatives, triterpenoids, steroids, saponosides, mucilages, reducing compounds, free anthracenes, combined $\mathrm{C}$-heterosides and combined O-heterosides. ${ }^{32}$ 


\section{Traditional and/or therapeutic uses}

In West Africa, M. lucida is an important plant in traditional medicine. Decoctions and infusions or plasters of roots, bark, and leaves are recognized cures for various types of ailments, including fever, malaria, trypanosomiasis, and outbreaks of fever during childbirth. A decoction of bark from the trunk is used to treat severe jaundice. The plant is also used in cases of diabetes, high blood pressure, helminthiasis, amenorrhoea, as a febrifuge, purgative, general analgesic, and laxative. The watery decoction of the fresh leaves is used as a body bath against skin rashes. M. lucida is cited in four African countries for its use against hepatitis. In Nigeria, it is one of the most widely used traditional cures for fever. The leaves, pressed and mixed with palm wine, are used against malaria and high blood pressure. ${ }^{64}$

\section{Moringa oleifera Linn}

\section{Botanical description of Morinda oleifera Linn}

M. oleifera is a species of a small tree that can grow up to 10 $\mathrm{m}$ high. It belongs to the Moringaceae family and the order of the Caporales. It is native to North India and is now acclimatised in almost all tropical regions. It resists drought well thanks to its tuberous roots which allow it to accumulate water. Its leaves are light green in color. The seeds of Moringa are oleaginous. The stem is aerial and erect; flexible in the young plant, strong, woody, and perennial in the adult plant. The stem may lose its leaves in the dry season, but the leaves grow back very quickly when conditions become favorable again. Moringa oleifera is fast growing. Moringa produces fruit in triangular capsules from February onwards. $^{22}$

\section{Chemical composition of Moringa oleifera}

Chemical screening of Moringa oleifera leaves shows that they are rich in sterols and triterpenes (terpenoids), carotenoids, essential amino acids, flavonoids, tannins, sugars, and fibres. Coumarin derivatives and alkaloids are in trace amounts. ${ }^{65}$

\section{Traditional and/or therapeutic uses}

M. oleifera is a plant commonly used in traditional medicine in various developing countries and modern medicine. The various parts of M. oleifera such as leaves, roots, seed, bark, fruit, flowers, and unripe pods are used by traditional practitioners in the treatment of various diseases (skin infections, etc.).

They act as cardiac and circulatory stimulants and have antitumor, antipyretic, antiepileptic, anti-inflammatory, antiulcer, antispasmodic, antioxidant, antidiabetic, antibacterial, antifungal, antidiarrheal, diuretic, and antihypertensive activities. They are also hypocholesterolemic, hepatoprotective, laxative and are used for the treatment of various ailments. In Senegal and Mali, $M$. oleifera leaves are used to treat stunted children. ${ }^{65}$

\section{Oldenlandia corymbosa $L$.}

\section{Botanical description of Oldenlandia corymbosa $\boldsymbol{L}$.}

$O$. corymbosa, of the family Rubiaceae, is an upright, sparsely branched plant. The leaves are opposite and indented, linear, and stalkless, with a toothed stipular collar. The white flowers are axillary, solitary, or assembled in small pauciflorous corymbs. The pedicels are located at the end of a separate peduncle, the whole measuring 5 to $20 \mathrm{~mm}$ long. The flowers have 4 fused sepals, surmounted by a spike, and 4 petals fused into a tube surmounted by 4 apiculate lobes. The fruit is a dehiscent capsule containing numerous conical seeds. This species can be confused with $O$. herbacea (Linnaeus) Roxburgh. The latter is distinguished by its abundant branching and the absence of a peduncle at the base of the flower pedicels. Also, the top of the capsule is flattened into an emarginate crest and protrudes beyond the teeth of the calyx. ${ }^{22}$

\section{Chemical composition of Oldenlandia corymbosa}

Phytochemical analysis showed the presence of sterols and triterpenes (terpenoids), carotenoids, essential amino acids, flavonoids, tannins, sugars, and fibres. ${ }^{22}$

\section{Traditional and/or therapeutic uses}

The infusion of the plant is mainly used in Imerina to reduce pain caused by gonorrhoea and gonorrhea itself. We have also noticed its favorable effects in rectites, as well as in small nervous accidents, menopausal disorders, etc. In Indian medicine, various Oldenlandia enjoy a great reputation. This plant is mainly used as a decoction for gastric disorders due to intermittent fevers and as a mild sedative in abnormal states of irritability and nervous breakdowns. ${ }^{22}$

\section{Parkia biglobosa (Jacq.) Benth}

\section{Botanical description of Parkia biglobosa}

P. biglobosa (Jacq.) Benth or the néré belonging to the Fabaceae family is a tree of 7 to $20 \mathrm{~m}$ in height. The height of the foot can exceptionally reach $30 \mathrm{~m}$. The leaves are bipinnate, alternating with rachis 20 to $40 \mathrm{~cm}$ long, and can bear 6 to 18 pairs of pines comprising 13 to 60 pairs of leaflets 1.5 to $2 \mathrm{~cm}$ long and 0.5 to $1.5 \mathrm{~cm}$ wide, with rounded tops and an asymmetrical base with 3 ribs on the upper surface and tightly packed together. The trunk, covered with ash-grey to grey-brown bark, often blackish, is deeply striated, giving a scaly, more or less quadrangular plate-like appearance to the adult tree, which is resistant to bush fires. The root system of the nere has a taproot with a diameter that becomes smaller as the root explores the depths of the soil. ${ }^{66}$

\section{Chemical composition of Parkia biglobosa}

Phytochemical screening mainly indicates the presence of catechic tannins, free flavonoids, and anthraquinones. ${ }^{67}$

\section{Traditional and/or therapeutic uses}

The use of néré is diversified in medicine and traditional pharmacopoeia. All parts of the tree are used either as the main recipe or in association with other trees for the care of various ailments. Indeed, the roots and bark are associated with other species to treat infertility, bronchitis, tracheitis, pneumonia, Sexually Transmitted Diseases (STDs), leprosy, rickets, colic, diarrhea. The bark is used to treat osteopathy and mumps. For the treatment of skin diseases, filariasis, edema, bronchitis, burns, hemorrhoids, the leaves are used; they are also used in the treatment of feverish states. The exocarp of the fruit is used against malaria attacks and the rind is used to treat soft warts and internal candidiasis. ${ }^{67}$

\section{Paullinia pinnata Linn.}

\section{Botanical description of Paullinia pinnata Linn}

P. pinnata is a plant of the Sapindaceae family that grows naturally in Brazil, South Africa, and Madagascar. It is widespread in secondary forest areas undergoing reforestation and along riverbanks in the savannah. It is also found from Senegal to Cameroon and in tropical America. It is commonly called Sweet gum in English, akan and Toa ntini (Ghana), Dzuhkelong in Baham, Cameroon, or Mbabi in Cameroon in the department of Lékie. This plant has been the subject of several studies thanks to its multiple uses in traditional medicine. ${ }^{68}$ 


\section{Chemical composition of Paullinia pinnata}

Phytochemical screening revealed the presence of alkaloids, catechic and gallic tannins, flavonoids, anthocyanins and leucoanthocyans, quinonic derivatives, triterpenoids, steroids, saponosides, reducing compounds, and free anthracenes. ${ }^{32}$

\section{Traditional and/or therapeutic uses}

The leaves are used in decoction to treat: fever, hypertension, and contraception in Ivory Coast in a locality called krobou in Agboville. In south-western Nigeria, the juice of the leaves is used to treat an inflamed throat and an infusion to lower fever. In Côte-d'Ivoire, the stem of the plant is used to treat rheumatism. The paste from the freshly crushed leaves is used locally to treat the fontanelle of infants. The plant is also used to cleanse pimples on the face and body. ${ }^{68}$

\section{Piliostigma thonningii (Sch.) Miln. Redh.}

\section{Botanical description of Piliostigma thonningii}

It is a shrub of 5 to $8 \mathrm{~m}$ in height with an often tortuous trunk, with bark deeply split longitudinally, dark brown, fibrous. It belongs to the Caesalpiniaceae family. The leaves are bilobed with a shallow notch at the top and an acute angle at the base. They are on average $12 \mathrm{~cm}$ wide and $14 \mathrm{~cm}$ long, 13 or 15 veins all start at the base and form a rough, dark brown patch. They are very prominent underneath. The inflorescences are small, protruding, or terminal in panicles. The flowers are whitish, grouped in small axillary or terminal racemes, with densely bronzed, ferruginous hairy sepals, about $2 \mathrm{~cm}$ wide. The fruits have an often twisted pod of about 20 times $4 \mathrm{~cm}$, dark brown in color when ripe, with a chocolaty, woody smell, covered with a compact ferruginous pubescence. The seeds are numerous, thick in the pulp. ${ }^{69}$

\section{Chemical composition of Piliostigma thonningii}

Phytochemical screening revealed the presence of alkaloids, catechic and gallic tannins, flavonoids, anthocyanins and leucoanthocyans, quinonic derivatives, triterpenoids, steroids, saponosides, reducing compounds, and free anthracenes. ${ }^{32}$

\section{Traditional and/or therapeutic uses}

P. thonningii is commonly used in traditional African medicine. Root preparations are applied to wounds and ulcers as a hemostat and to promote healing. They are also used for their diuretic properties and the treatment of diarrhea, dysentery, worms, and other intestinal problems. This plant is used to treat rheumatism. Root preparations are cures for coughs, colds, chest pains, pneumonia, diarrhea, dysentery, worms, and other intestinal problems, and snake bites. The bark is believed to have an analgesic action and is used in the treatment of sore throat, toothache, gum disease, earache, stomach ache, and body aches. In East Africa, bark juice, or boiled bark, is drunk as a treatment for gonorrhoea. ${ }^{70}$

\section{Pteleopsis suberosa Engl. and Diels}

\section{Botanical description of Pteleopsis suberosa}

A small tree 6-7 $\mathrm{m}$ high with a more or less straight upright, hail-bearing, cylindrical shaft. It belongs to the Combretaceae family. Very characteristic bark, coarsely and densely covered with corky warts (which make it easy to recognize even when it is defoliated), grey ramification. Leaves opposite or sometimes alternate, oval, pinnate veins, greenish yellow flowers. Fruits samara pedicellate in the shape of a brown pear when ripe. ${ }^{39}$

\section{Chemical composition of Pteleopsis suberosa}

Phytochemical screening mainly indicates the presence of catechic tannins, free flavonoids, and anthraquinones. ${ }^{39}$

\section{Traditional and/or therapeutic uses}

The leaf decoction is used against meningitis, convulsions, and headaches. The decoction is used in gastric and duodenal ulcers, treatment of cough, mouth ulcer, asthma, hemorrhoids, oral measles, treatment of digestive mycosis, and abdominal pain. The stem bark is used to increase cereal production. This plant also has anti-inflammatory, anti-ulcer, antitussive, anti-tumor, antibacterial, antifungal, and antioxidant properties. ${ }^{39}$

\section{Rauvolfia vomitoria Afzel}

\section{Botanical description of Rauvolfia vomitoria Afzel}

It is a species belonging to the family Apocynaceae. small to medium size tree reaching $20 \mathrm{~m}$ high and $80 \mathrm{~cm}$ in diameter; bark pale to dark grey-brown or dark brown, smooth or cracked. Leaves in whorls, grouped at the tips of the branches, single and whole. Flowers are bisexual, regular, and fragrant. Fruits are globose to ovate or ellipsoid drupes $8-14 \mathrm{~mm}$ long, orange or red, containing 1 seed. Seeds are ellipsoid, 6-8 mm long, laterally compressed..$^{70}$

\section{Chemical composition of Rauvolfia vomitoria}

Phytochemical screening carried out on leaves and bark showed the presence of flavonoids, anthraquinones, tannins, reducing compounds, mucilages, and coumarins. ${ }^{70}$

\section{Traditional and/or therapeutic uses}

Throughout its range, the roots of $R$. vomitoria are taken as a decoction, macerated or powdered in water to treat diarrhea, rheumatism, jaundice, venereal diseases, and snake bites. Root products are commonly taken to treat high blood pressure and are used as a sedative to calm epileptics. When used externally, the macerated or powdered root and sometimes the pulpy fruit is used to treat all kinds of skin problems, such as rashes, scabs, chicken pox, wounds, scabies, psoriasis, leprosy, lice, and parasitic diseases. The root decoction is used as a mouthwash against gingivitis or thrush. The bark of the stem or leaves is also used for these effects, but to a lesser extent. Stem bark, decoction leaves, and latex from young twigs are commonly used as a purgative or emetic. In Guinea, root maceration is applied to tumors. In Liberia, bark infusion is used to treat fever. Dried or fresh roots powdered in palm wine or oil are used to treat female infertility. ${ }^{70}$

\section{Sanseviera liberica Ger. and Labr.}

\section{Botanical description of Sanseviera liberica}

It is a perennial herbaceous plant, rhizomatous, stemless; rhizome rounded, underground, about $19 \mathrm{~mm}$ in diameter, branched. It belongs to the Agavaceae family. Leaves stipulate absent; petiole absent; blade oblanceolate, erect to suberect, spreading with age, dark green usually with indistinct lighter bands, transverse, apex narrowed, ending in a soft, sharp, greenish-white tip, cartilaginous margin, pale reddish-brown. The inflorescence is a spiciform, loosely flowered, spiciform cluster, stalk with evergreen membranous bracts, lower bracts approx. $4 \mathrm{~cm}$ long. Flowers bisexual, regular, pedicel about $5 \mathrm{~mm}$ long; perianth tuberous, filiform and long style, heady stigma. ${ }^{69}$

\section{Chemical composition of Sanseviera liberica}

Phytochemical analysis showed the presence of alkaloids, tannins, flavones, coumarins, saponins, sterols, triterpenes, and reducing compounds. ${ }^{69}$

\section{Traditional and/or therapeutic uses}

In traditional medicine, the juice squeezed from the leaves or leaf decoction is taken as a drink to treat gonorrhoea, earache, and 
toothache. Leaf juice is applied to ulcers, wounds and as a topical application for earache and toothache. Fermented rhizomes are consumed to treat malaria. A root decoction is used as a cure for convulsions. In Ghana, roots are used for their abortive virtues and administered during childbirth. As a fetish plant, it is cultivated on graves, in shrines, and enclosures. Sansevieria liberica is widely cultivated as an ornamental plant. ${ }^{69}$

\section{Sarcocephalus latifolius (Sm.) E.A.Bruce}

\section{Botanical description of Sacrocephalus latifolius}

Of the Rubiaceae family, it is a more or less sarmy tree or shrub 4-5m high, with a tortuous shaft and up to $30 \mathrm{~cm}$ in diameter, with a spreading, open crown, with flexible, intertwined, erect, and then drooping branches. Bark cracked, dark grey-brown, with reddish fibrous edges. Stipules arranged in two between the leaves, thin, triangular collar with pointed apex, rounded 0.3-0.7 cm long. Leaves opposite, hairless, broadly elliptic, and suborbicular. Flowers more or less pinkish-white, small, corolla-like flowers in a tube with 4 more or less ciliated lobes with the club-like style exceeding S-8 mm. Fleshy, irregularly globose berry fruit, $3-5 \mathrm{~cm}$ in diameter, red to dark brown when ripe, with a surface riddled with shallow cells containing a large number of seeds embedded in a pinkish flesh with a strawberry odour. ${ }^{69}$

\section{Chemical composition of Sarcocephalus latifolius}

Phytochemical analysis showed the presence of sterols and triterpenes (terpenoids), carotenoids, essential amino acids, flavonoids, tannins, sugars, and fibres. ${ }^{65}$

\section{Traditional and/or therapeutic uses}

Leaves, roots, bark, and fruit are used in the pharmacopoeia. These different parts of the plant are used to treat illnesses such as deworming, fever, malaria, constipation, colic, gonorrhoea, syphilis, abscesses, vomiting, and others. It is also used to treat other diseases such as diabetes and menstrual disorders. It is mainly used by African women in Kinshasa for their intimate hygiene and also has veterinary properties such as the treatment of Pasteurellosis cattle. In the medicinal plant trade, the roots of $S$. latifolius are the most common sale in Benin. In Cameroon, its roots are used for fever, convulsions, headaches, inflammatory, and neuropathic treatments while the leaves are involved in the treatment of system disorders such as epilepsy or anxiety. Its roots are the most widely used plant parts in medicine. The high use of its roots against diarrhoeal infections is linked to their coumarins and polyphenolic compounds which have anti-inflammatory, antimicrobial, and anticoagulant properties. ${ }^{65}$

\section{Thonningia sanguinea Vahl.}

\section{Botanical description of Thonningia sanguinea}

T. sanguinea, also known as the White Doe Palm is a plant of the family Balanophoraceae. It belongs to the family Balanophoraceae. This plant of the genre Thonningia is a species native to Africa. This species is a holoparasite found on trees. The plant parasitizes palm, rubber, and cocoa plants. It is unable to produce chlorophyll and is dependent on its host. It is usually a little less than $20 \mathrm{~cm}$ high. Only the inflorescence is seen above ground, at about $7 \mathrm{~cm}$ high, and is pink in color. ${ }^{69}$

\section{Chemical composition of Thonningia sanguinea}

Phytochemical analysis showed the presence of sterols and triterpenes (terpenoids), carotenoids, essential amino acids, and flavonoids. ${ }^{69}$

\section{Traditional and/or therapeutic/pharmacological uses}

The whole crushing plant is used in cases of dysentery; prepared as an ointment, it treats swellings; as a poultice, it helps abscesses to mature; and finally crushed and diluted in water, it is used as a mouthwash to counter cavities, gingivitis, and other oral infections. The root is used as a vermifuge; a root decoction treats rheumatism. The flower is used as a decoction to treat sore throats and laryngitis; it is also used as a vermifuge when mixed with other plants; crushed and mixed with chilli pepper, it forms a paste and is used as an enema in case of haemorrhoids or is rubbed on the nape of the neck in case of torticollis; the juice from the pressed flowers is used as an instillation for the eyes of stunted children and premature babies. The rhizome and flowers are processed into an ointment to treat dermatological problems. ${ }^{69}$

\section{Ocimum gratissimum Linn.}

\section{Botanical description of Ocimum gratissimum Linn}

This herbaceous plant with a very rigid stem can grow up to 2 $\mathrm{m}$ high. Belonging to the Lamiaceae family, it has opposite pale green, oval, slightly tapering, and serrated leaves that give off an aromatic scent. When flowering, the plant bears small white, pinkish-white, or carmine red flowers arranged in long clusters or spikes that can be up to $15 \mathrm{~cm}$ long. The calyxes produce four small black seeds. Originally from South-East Asia, this basil is now found throughout the tropics. ${ }^{70}$

\section{Chemical composition of Ocimum gratissimum}

Phytochemical screening shows that in addition to the presence of the three (03) groups of phenolic, nitrogen, steroid, and terpenoid compounds, we have cyanogenic derivatives, mucilages, and reducing compounds. ${ }^{68}$

\section{Traditional and/or therapeutic uses}

The leaves of this plant are antibacterial, antidiarrheal, antifungal, healing, anesthetic, and stimulating. The decoction of 30 grams of leaves in a liter of water, drunk during the day, is useful for treating many ailments: abdominal pain, painful periods, difficult digestion, sore throat, angina, gingivitis, dental pain, white discharge, wounds, ulcers, abscesses, boils and fungal infections (candidiasis and ringworm). The raw juice of the washed and crushed leaves, to which honey can be added, is used to treat coughs. This juice can also be used to heal wounds. The salty decoction of the leaves is given to women to drink immediately after giving birth in case of pain. The plant, which is known as "warm", warms the body and prevents the blood from clotting after the "cold" caused by childbirth. As a rule, the mother usually takes a steam bath with this decoction immediately after giving birth and then repeats the operation twice at an interval of one week. The leaves of this basil are also used in inhalation to treat bronchitis and sinusitis. ${ }^{70}$

\section{Waltheria indica Linn}

\section{Botanical description of Waltheria indica Linn}

$W$. indica, of the family Sterculiaceae, is a woody plant with hardy or annual stump. The plant is widespread in subtropical and tropical regions. It is a short-lived shrub reaching about $2 \mathrm{~m}$ in height and $2 \mathrm{~cm}$ in stem diameter. The roots are brown and flexible and have a single solid stem emerging from the ground. The leaves are dense to slightly pubescent and tomentose. The glomerulus contains yellow to orange flowers and reproduction is by seed. The flowers are a source of nectar for bees and wasps and can be useful for pollination in disturbed areas or agro-ecosystems. ${ }^{70}$ 


\section{Chemical composition of Waltheria indica}

The phytochemical analysis of Waltheria indica contains different chemical groups, including alkaloids, flavonoids, sterols, terpenes, cardiac glycosides, saponins, anthraquinones, and carbohydrates. $^{70}$

\section{Traditional and/or therapeutic uses}

This plant is used for the treatment of simple ailments (sore throat, cough) and complicated ailments (inflammation and asthma). In Hawaii, the root is chewed to relieve sore throats and in Burkina Faso, it is used to treat gum and tooth diseases. Various extracts, decoction or maceration, are used in inflammation or conditions of inflammation: rheumatism in Mexico, gingivitis in Brazil, asthma in Hawaii, and Burkina Faso. Waltheria indica is used to treat diarrhea by traditional healers in Nigeria. Besides, it is traditionally used to treat malaria, dysentery, hemorrhoids, cancer, leprosy, epilepsy, syphilis, infertility, erectile dysfunction, and impotence. The plant is also used in Togo against infectious diseases. ${ }^{70}$

\section{Xylopia aethiopica (Dunal) A. Rich.}

\section{Botanical description of Xylopia aethiopica}

It is a tree with a straight shaft that can reach a height of $20 \mathrm{~m}$. It is a tree of the Annonaceae family. The leaves are oblong-throated, obtuse or rounded at the base, acuminate, hairless, glaucous underneath, 4 to $10 \mathrm{~cm}$ long, 2 to $4 \mathrm{~cm}$ wide. The flowers are greenish-white, fragrant. The cylindrical, linear fruits are arranged in flower heads and form bouquets of 12 to 20 bacciform capsules. It is a species of the Guinean zone located in humid or swampy soils, known from Senegal to Gabon. The fruit is used in the composition of many medicinal preparations and especially as a spice in cooking, either in powder form or whole. ${ }^{67}$

\section{Chemical composition of Xylopia aethiopica}

Phytochemical screening has revealed the presence of alkaloids, catechic and gallic tannins, flavonoids, anthocyanins and leucoanthocyans, derivatives of quinonics, triterpenoids, steroids, saponosides, reducing compounds, and free anthracenes. ${ }^{32}$

\section{Traditional and/or therapeutic uses}

Several parts of the plant are used in traditional medicine to treat various ailments. The fragrant bark is used to treat colds, bronchitis, and pneumonia and as a painkiller. The macerated inner bark is applied to oedemas to reduce them, and the preparation based on slivers of inner bark soaked in water is used as a mouthwash in case of pyorrhoea. In Nigeria, bark powder is applied to ulcers and in Gabon the lotion prepared from bark treats headaches. Root powder fights constipation, treats gum lesions and inflammation, and is also used to treat cancer. Fruits are eaten to help with childbirth and to treat bronchitis and gonorrhea. The decoction of leaves, stem bark, and roots are used as a general tonic and in the treatment of rheumatism and stomach pain. The presence of alkaloids, flavonoids, coumarins, tannins, and saponosides has been demonstrated in several parts of the plant. ${ }^{68}$

\section{Zanthoxylum xanthoxyloides Lam.}

\section{Botanical description of Zanthoxylum xanthoxyloides Lam.}

It is a shrub or small tree, thorny and more or less scandalous, reaching 6 to $8 \mathrm{~m}$ in height. The bark is grey to beige, rough, with fine vertical cracks. The leaves are alternate and hairless. This plant species belongs to the Rutaceae family. The flowers are unisexual, regular, white or greenish, stalkless, corolla barely open. The male flowers have slightly exserted stamens and the female flowers have an upper ovary. ${ }^{66}$

\section{Chemical composition of Zanthoxylum xanthoxyloides}

Phytochemical screening has revealed the presence of alkaloids, coumarins, pyranocoumarins, aromatic amides, lignans, alkylamides, flavonoids, and triterpenoids. ${ }^{66}$

\section{Traditional and/or therapeutic uses}

Throughout West Africa, aromatic roots, stem bark, and leaves are commonly used in traditional medicine. They are considered antiseptics, analgesics, and diaphoretics. Macerations, decoctions, or infusions of root or stem bark are widely used to treat malaria, fever, sickle cell anemia, tuberculosis, paralysis, edema, and general body weakness. They are also used to treat intestinal problems, including colic, dysentery, intestinal worms, gonorrhoea, and urethritis, but also as an emmenagogue, stimulant and to treat pain during childbirth, migraine, and neuralgia. The roots are applied externally on ulcers, swellings, hemorrhoids, abscesses, snake bites, yaws, wounds, leprosy, and syphilitic wounds as well as rheumatic and arthritic pain and hernias. The root decoction is used as a mouthwash and for sore throats. ${ }^{66}$

\section{Conclusions}

From all of the above, it can be concluded that medicinal plants are a very effective alternative for the treatment of infectious diseases and could replace modern molecules that are less effective and increasingly decried because of bacterial resistance. These plants must therefore be studied in greater depth to determine the major chemical groups, the effectiveness of the plants, and their toxicity.

\section{References}

1. Muthu C, Ayyanar M, Raja N, Ignacimuthu S. Medicinal plants used by traditional healers in Kancheepuram District of Tamil Nadu, India. J Ethnobiol Ethnomed 2006;2:1-7. DOI: http:doi:10.1186/1746-4269-2-43.

2. N'Guessan K, Kadja B, Zirihi G, et al. Screening phytochimique de quelques plantes médicinales ivoiriennes utilisées en pays Krobou (Agboville, Côte-d'Ivoire). Sci Nat 2009;6:1-15. DOI: http://dx.doi.org/10.4314/ijbcs.v4i4.63039.

3. Marius L, Calixte B, N'guéssan B, et al. Analyse phytochimique et évaluation de la toxicité aiguë par voie orale chez des rats de l'extrait total aqueux des feuilles de Abrus precatorius Linn (Fabaceae). Int J Biol Chem Sci 2015;9:1470-6. DOI: http://ajol.info/index.php/ijbcs.

4. Suralkar AA, Kasture SB. Inhibitory effect of Abrus precatorious extract on bronchial hyper-reactivity induced by ovalbumin in experimental animals. Int J Pharm Pharm Sci 2013;5:403-4.

5. Garaniya N, Bapodra A. Ethno botanical and Phytophrmacological potential of Abrus precatorius L.: A review. Asian Pacific J Trop Biomed 2014;4:27-34. DOI: https://doi.org/10. 12980/APJTB. 4.2014C1069.

6. Prenner G. Flower development in Abrus precatorius (Leguminosae: Papilionoideae: Abreae) and a review of androecial characters in Papilionoideae. South Afr J Botany 2013;89:210-8. DOI: https://doi.org/10.1016/j.sajb.2013.06. 008

7. Ezuruike UF, Prieto JM. The use of plants in the traditional management of diabetes in Nigeria: Pharmacological and toxicological considerations. J Ethnopharmacol 2014;155:857-924. DOI: https://doi.org/10.1016/j.jep.2014.05.055

8. Kebenzikato AB, Wala K, Dourma M, et al. Distribution et struc- 
ture des parcs à Adansonia digitata L.(baobab) au Togo (Afrique de l'Ouest). Afrique Science 2014;10:434-49. DOI: https://doi.org/10.1016/j.jep.2009.10.031

9. Agbankpé JA, Dougnon TV, Bankole HS, et al. Etude ethnobotanique des légumes feuilles thérapeutiques utilisés dans le traitement des diarrhées au sud-Bénin (Afrique de l'Ouest). Int J Biol Chem Sci 2014;8:1784-95. DOI: http://ajol.info/ index.php/ijbcs

10. Ilic N, Schmidt BM, Poulev A, Raskin I. Toxicological evaluation of grains of paradise (Aframomum melegueta)[Roscoe] K. Schum. J Ethnopharmacol 2010;127:352-6. DOI: https://doi.org/10.1016/j.jep.2009.10.031

11. Chah KF, Eze CA, Emuelosi CE, Esimone C. Antibacterial and wound healing properties of methanolic extracts of some Nigerian medicinal plants. J Ethnopharmacol 2006;104:164-7. DOI: https://doi.org/10.1016/j.jep.2005.08.070

12. Umukoro S, Ashorobi RB. Pharmacological evaluation of the antidiarrhoeal activity of Aframomum melegueta seed extract. West Afr J Pharmacol Drug Res 2003;19:51-4. DOI: http://dx.doi.org/10.4314/wajpdr.v19i1.14734

13. Inegbenebor U, Ebomoy, M, Onyia KA, et al. Effect of alligator pepper (Zingiberaceae aframomum melegueta) on first trimester pregnancy in Sprague Dawley rats. Nigerian J Physiol Sci 2009;24. DOI: http://dx.doi.org/10. 4314/njps. v24i2.52901

14. Sobolewska D, Podolak I, Makowska-Wąs J. Allium ursinum: botanical, phytochemical and pharmacological overview. Phytochem Rev 2015;14:81-97. DOI: https://doi.org/10. 1016/j.jep.2008.11.006

15. El Kalamouni C. Caractérisations chimiques et biologiques d'extraits de plantes aromatiques oubliées de Midi-Pyrénées. PhD These. Institut National Polytechnique de Toulouse, France. 2010.

16. Radulović NS, Miltojević AB, Stojković MB, Blagojević P. New volatile sulfur-containing compounds from wild garlic (Allium ursinum L., Liliaceae). Food Res Int 2015;78:1-10. DOI: https://doi.org/10.1016/j.foodres.2015.11.019

17. Iwueke A, Nwodo O, Ojiako O, et al. Modification of lipid peroxidation and oxidative stress in hepatocytes of diabetic rats treated with root extract of Sarcocephalus latifolius and Daniella oliveri. Austr J Basic Appl Sci 2010;4:3578-84. DOI: https://doi.org/10.1016/j.jep.2009.10.031

18. Ghali A, Rafed S. Screening phytochimiques et activité antihémolytique de deux plantes médicinales: Alluim ursinum et Allium porrum. Mémoire de Master en Science de la Nature, de la Vie et de la Terre, Université de Bouira, 2019.

19. N'guessan K. Contribution à l'étude ethnobotanique en pays Krobou (Côte d'Ivoire). Thèse de Doctorat de 3ème cycle, Université de Cocody, Abidjan, Côte d'Ivoire, 2000.

20. Fofana S. Exploration biochimique sur le pouvoir immunogène de trois plantes en Côte d'Ivoire: Alstonia boonei (Apocynaceae), Mitragyna ciliata (Rubiaceae) et Terminalia catappa (Combretaceae). Diplôme d'Etat de Doctorat en pharmacie, Fac. Med., Pharm. Et Odon, Université de Bamako, Mali 2004.

21. Arbonnier M. Arbres, Arbustes et Lianes des Zones Sèches d'Afrique de l'Ouest. Editions Quae: 2009.

22. N'guessan K, Zirihi NG, Boraud N. Étude ethnopharmacologique des plantes utilisées pour faciliter l'accouchement, en pays Abbey et Krobou, au Sud de la Côte-d'Ivoire. Int J Biol Chem Sci 2010;4:1004-16. DOI: http://dx.doi.org/10. 4314/ijbcs.v4i4.63039

23. Muanda F, Koné D, Dicko A. et al. Phytochemical composition and antioxidant capacity of three malian medicinal plant parts. Evidence-Based Complem Altern Med 2011;1-8. DOI: https://doi.org/10.1093/ecam/nep109

24. Dandjesso C, Klotoé JR, Dougnon TV, et al. Phytochemistry and hemostatic properties of some medicinal plants sold as anti-hemor- rhagic in Cotonou markets (Benin). Indian J Sci Technol 2012;5:3105-9. DOI: https://doi.org/10.1002/ptr.995.

25. Okhale SE, Akpan E, Fatokun OT, et al. Annona senegalensis Persoon (Annonaceae): a review of its ethnomedicinal uses, biological activities and phytocompounds. J Pharmacogn Phytochem 2016;5:211-9. DOI: https://doi.org/10.1016/j.jep. 2016.11.006

26. Muhali OJ, Olowokudejo JD. Leaf epidermal morphology and petiole anatomy of the genus Anthocleista Afzel. ex R. Br.(Gentianaceae). J Trop Agricult 2017;55:1-5. DOI: https://ir.unilag.edu.ng/handle/123456789/5585

27. Bassey AS, Okokon JE, Etim E, Umoh F, Bassey E. Evaluation of the in vivo antimalarial activity of ethanolic leaf and stembark extracts of Anthocleista djalonensis. Indian J Pharmacol 2009;41:258-261. DOI: 10.4103 / 0253-7613.59924

28. Bi SN, Traore F, Soro TY, Souza A. Etudes phytochimique et pharmacologique de Bridelia ferruginea Benth (Euphorbiaceae) sur la motricité du Taenia coli de cobaye. Afrique Science 2009;5:297303. DOI: https://doi.org/10. 1016/j.jep.2009.08.070

29. Basu S, De AK. Capsicum: historical and botanical perspectives. In: De AK (ed), Capsicum. CRC Press 2003: 21-35.

30. Masi L, Siviero P, Castaldo D, et al. Agronomic, chemical and genetic profiles of hot peppers (Capsicum annuumssp.). Molecular Nutr Food Res 2007;51:1053-62. DOI: https://doi.org/10.1002/mnfr.200600233

31. Elegami A, El-Nima EI, Tohami ME, Muddathir AK. Antimicrobial activity of some species of the family Combretaceae. Phytotherapy Research. Int J Dev Pharmacol Toxicol Evaluation Natural Product Der 2002;16:555-61. DOI: https://doi.org/10.1002/ptr.995

32. Brondani RP, Gaiotto FA, Missiaggia A, et al. Microsatellite markers for Ceiba pentandra (Bombacaceae), an endangered tree species of the Amazon forest. Molecular Ecol Notes 2003;3:1779. DOI: https://doi.org/10.1046/j.1471-8286. 2003.00389.x

33. Pattigadapa HS, Ramesh M, Sagar CP, et al. Cardiotonic activity of coconut water (Cocos nucifera). Recent Res Sci Technol 2011;3:155-8. DOI: https://doi.org/10.1016/j.sajb.2011.06.008

34. Karadi RV, Shah A, Parekh P, Azmi P. Antimicrobial activities of Musa paradisiaca and Cocos nucifera. Int J Res Pharmaceut Biom Sci 2011;2:264-7. DOI: https://doi.org/10.1016/j.jep. 2009.10.031

35. Oliveira LMB, Bevilaqua CML, Costa CC, et al. Anthelmintic activity of Cocos nucifera L. against sheep gastrointestinal nematodes. Veterinary Parasitology 2009;159:55-9. DOI: https://doi.org/10.1016/j.vetpar.2008.10.018.

36. Adomou AC, Yedomonhan H, Djossa B, et al. Etude Ethnobotanique des plantes médicinales vendues dans le marché d'Abomey-Calavi au Bénin. Int J Biol Chem Sci 2012;6:745-72. DOI: http://dx.doi.org/10.4314/ijbcs.v6i2.18

37. Dogan Y, Baslar S, Ay G, Mert, H. The use of wild edible plants in western and central Anatolia (Turkey). Economic Botany 2004;58:684-90. DOI: https://doi.org/10.1002/ptr.995

38. Chindo BA, Amos S, Odutola A, et al. Central nervous system activity of the methanol extract of Ficus platyphylla stem bark. J Ethnopharmacol 2003;85:131-7. DOI: https://doi.org/10. 1016/S0378-8741(02)00376-8

39. Sangare M, Bayala B, Ategbo JM, et al. Effets de l'extrait aqueux de gomphrena celosioides (amaranthaceae) sur les enzymes hépatiques. Afrique Science 2012;8:107-15. DOI: http://dx.doi.org/10.4314/wajpdr.v19i1.14734.

40. Onocha PA, Ajaiyeoban EO, Dosumu OO, Ekundayo O. Phytochemical screening and Biological activities of Gomphrena celosioides (C. Mart) Extracts. Nigerian Soc Exp Biol J 2005;5:59-65. DOI: https://doi.org/10.1016/j.jep.2008. 11.006

41. Cisse M, Dornier M, Sakho M, et al. Le bissap (Hibiscus sabdariffa 
L.): composition et principales utilisations. Fruits 2009;64:179 193. DOI: https://doi.org/10.1051/fruits/ 2009013

42. Mohamed R, Fernandez J, Pineda M, Aguilar M. Roselle (Hibiscus sabdariffa) seed oil is a rich source of $\gamma$-tocopherol. J Food Sci 2007;72:207-11. DOI: https://doi.org/10.1111/j. 17503841.2007.00285.x

43. Babalola SO. Chemical composition of roselle (Hibiscus sabdariffa L.) leaf. Proc. 24th Ann. Conf. Nigerian Inst. Food Sci. Technol 2000 ; 4(8): 119-121.

44. Bayala B. Activité progestative et activité oestrogénique de Holarrhena floribunda (G. Don) Durand et Schinz (Apocynaceae), une plante de la pharmacopée traditionnelle du Burkina Faso $(\mathrm{PhD}$ Thesis). Thèse de Doctorat Sciences Biologiques Appliquées, Université de Ouagadougou 2005.

45. Karou D, Dicko MH, Simporé J, et al. Activités antioxydantes et antibactériennes des polyphénols extraits de plantes médicinales de la pharmacopée traditionnelle du Burkina Faso. Mémoire de maitrise, Université de Ouagadougou, 2005.

46. Oduola T, Avwioro OG, Ayanniyi TB. Suitability of the leaf extract of Jatropha gossypifolia as an anticoagulant for biochemical and haematological analyses. Afr J Biotechnol 2005;4:679-681. DOI: http://dx.doi.org/10.5897/AJB2005. 000-3125.

47. Hosamani KM, Katagi KS. Characterization and structure elucidation of 12-hydroxyoctadec-cis-9-enoic acid in Jatropha gossypifolia and Hevea brasiliensis seed oils: a rich source of hydroxy fatty acid. Chemistry Physics Lipids 2008;152:9-12. DOI: https://doi.org/10.1016/j.chemphyslip.2007.11.003

48. Arnold R. Khaya senegalensis - current use from its natural range and its potential in Sri Lanka and elsewhere in Asia. In: Prospects for High-Value Hardwood Timber Plantations in the Dry Tropics of Northern Australia Mareeba, 19th - 21st October 2004.

49. Grace OM, Light ME, Lindsey KL, et al. Antibacterial activity and isolation of active compounds from fruit of the traditional African medicinal tree Kigelia africana. South Afr J Bot 2002;68:220-2. DOI: https://doi.org/10.1016/S0254-6299(15)30424-5

50. d'Ivoire C, Alphonse AK, Albert YK, et al. Comportement de deux morphotypes de Lippia multiflora (Verbenaceae) sur ferralsols de la région de Yamoussoukro, Côte d'Ivoire. J Appl Biosci 2011;38:2592-2601. DOI: https://doi.org/10.1051/ fruits/2011013

51. Agnaniet H, Makani T, Akagah A, et al. Volatile constituents and antioxidant activity of essential oils from Lippia multiflora Mold. growing in Gabon. Flavour Fragrance J 2005;20:34-8. DOI: https://doi.org/10.1002/ffj.1383.

52. Okoh SO, Asekun OT, Familoni OB, Afolayan AJ. Composition and antioxidant activities of leaf and root volatile oils of Morinda lucida. Natural Prod Comm 2011;6:1-5. DOI: $1934578 X 1100601032$.

53. Raji Y, Akinsomisoye OS, Salman TM. Antispermatogenic activity of Morinda lucida extract in male rats. Asian J Andrology 2005;7:405-10. DOI: https://doi.org/10. 1016/j.sajb.2005. 06.008.

54. Foidl N, Makkar H, Becker K. The potential of Moringa oleifera for agricultural and industrial uses. The miracle tree: The multiple attributes of Moringa. Sci Educ 2001;3:45-76. DOI: 10.12691/ajfst-3-6-1

55. Lassen KM. Pollination of Parkia Biglobosa in the Gambia: With Focus on Honeybees as Pollinators. PhD Thesis. Royal Veterinary and Agricultural University, Department of Agricultural 2004.

56. Millogo AMD. Etude des caractéristiques morphologiques et de la viabilité des semences de Parkia biglobosa (Jacq.) Rapport d'activité. Burkina-Faso 2014.

57. Ngono XR, Tembe EF, Ngameni B, Njinkio BN, Fokunang CN. Screening Phytochimique, Propriétés Analgésiques et Toxicité Aigüe de l'Extrait Aqueux des Écorces de la Tige de Paullinia Pinnata (Sapindaceae). Health Sci Dis 2019;20:7-18. DOI: http://dx.doi.org/10.4314/ijbcs.v4i4.63039

58. Aderogba MA, Okoh EK, Adelanwa T, Awolowo O. Antioxidant properties of the Nigerian Piliostigma species. J Bio Sci 2004;4:501-3. DOI: http://dx.doi.org/10.3923/jbs. 2004.501.503

59. Akinpelu DA, Obuotor EM. Antibacterial activity of Piliostigma thonningii stem bark. Fitoterapia 2000;71:442-3. DOI: https://doi.org/10.1016/S0367-326X(00)00136-2.

60. De Leo M, Braca A, Sanogo R, et al. Antiproliferative activity of Pteleopsis suberosa leaf extract and its flavonoid components in human prostate carcinoma cells. Planta Medica 2006;72:604-10. DOI: $10.1055 / \mathrm{s}-2006-931556$

61. Pedersen ME, Vestergaard H, Hansen SL, Bah S, Diallo D, Jäger AK. Pharmacological screening of Malian medicinal plants used against epilepsy and convulsions. J Ethnopharmacol 2009;121:472-5. DOI: https://doi.org/10. 1016/j.jep.2008. 1.006.

62. Nwodo NJ, Okide GB, Okonta JM, Ebebe IM. Antidiabetic effect of Rauwolfia vomitoria ethanolic leaf extract in rabbits. J Trop Med Plant 2003;4:71-4. DOI: https://doi.org/10. 1016/j.jep. 2003.11.006.

63. Akoègninou A, Van der Burg W, Van der Maesen G. Flore analytique du Bénin. Livre scientifique, Leiden: Backhuys Publishers, 2006.

64. Ikewuchi CC. Effect of aqueous extract of Sansevieria senegambica Baker on plasma chemistry, lipid profile and atherogenic indices of alloxan treated rats: Implications for the management of cardiovascular complications in diabetes mellitus. Pac J Sci Technol 2010;11:524-31. DOI: https://doi.org/10. 1016/j.jep. 2009.10.031

65. Kaboré SA, Hien M, Ouédraogo D, Diallo TR, Hahn K, Nacro HB. Use of ecosystem services of Sarcocephalus latifolius (Sm.) EA Bruce and induced effect of human pressure on the species in the Southwestern Region of Burkina Faso. Ethnobotany Res Appl 2014;12:561-70.

66. Zongo R. Caractérisation chimique et biologique de Waltheria indica L.(Malvaceae), herbacée utilisée en médecine traditionnelle au Burkina Faso pour la prise en charge de l'asthme. PhD These. Université de Ouagadougou, 2013.

67. Hawthorne WD, Jongkind C. Woody plants of Western African forests, A guide to the forest trees, shrubs and lianes from Senegal to Ghana. Livre scientifique. Royal Botanic Gardens, Kew. 2006.

68. Bobboi A, Gidado A, Edeoji I, Milala MA. The Effects Of The Root Of Xylopia quintasii On Blood, Liver And Kidney Function Indices In Rats. Nigerian J Natural Products Medi 2004;8:52-4. DOI: http://dx.doi.org/10.4314/njnpm. v8i1.11816.

69. Ahua KM, Ioset JR, Ioset KN, et al. Antileishmanial activities associated with plants used in the Malian traditional medicine. J Ethnopharmacol 2007;110:99-104. DOI: https://doi.org/10. 1016/j.jep.2006.09.030

70. Ahua KM, Ioset JR, Ioset KN, et al. Antileishmanial activities associated with plants used in the Malian traditional medicine. J Ethnopharmacol 2007;110:99-104. DOI: https://doi.org/ 10.1016/j.jep.2006.09.030 